\title{
The Development of a Conceptual Model Promoting Learners' Ownership in an Online Learning Environment
}

\author{
Divina C. Casim ${ }^{1} \&$ Yong-Chil Yang ${ }^{2}$ \\ ${ }^{1}$ Pampanga Agricultural College, Philippines \\ ${ }^{2}$ Andong National University, Andong, Korea \\ Correspondence: Yong-Chil Yang, Andong National University, Andong, Kyungbuk 750-749, Korea. Tel: \\ 82-54-820-5585. E-mail: ycyang@andong.ac.kr
}

\author{
Received: October 15, 2012 Accepted: October 25, 2012 Online Published: December 31, 2012 \\ doi:10.5539/ass.v9n1p9 \\ URL: http://dx.doi.org/10.5539/ass.v9n1p9
}

\begin{abstract}
The purpose of this study was to explore the development of a conceptual model that promotes ownership in an online learning environment. It proceeds toward building a comprehensive online learning model that illustrates the interrelationship among learning motivation, cognition and meta-cognition. Those components can be employed into strategies to promote the learner ownership that is assumed to be an essential factor influencing learners' achievement. The main methods of the study were literature review about ownership and development research on building of a conceptual model. A conceptual model of learners' ownership in an online learning environment is proposed into integration of three factors of learning motivation, cognition, and meta-cognition and Milner-Bolotin's three categories of ownership (2001), which are composed of personal value, control and responsibility. Since the model is a hypothetical and conceptual, further research for testing its theoretical validity is needed.
\end{abstract}

Keywords: ownership, conceptual model, online learning

\section{Introduction}

The fast growing information technology extensively increases online learning environments (OEL) such as e-learning, mobile learning, or smart learning. Although OEL is characterized by being taught anytime, anywhere, anyhow and any content, it poses dangers to learners' experiences like early withdrawal or drop-out from online learning due to poor learning skills or sense of isolation. Thus, it is required that online learners have effective learning skills to proceed responsibly online learning, and then to enable them to become self-regulated learners. In order to help learners effectively in online settings, Milner-Bolotin (2001) suggested learners have ownership to online learning settings, and that there are three categories of ownership to online learning. According to the suggestion, the categories of ownerships are composed of three components. First, finding personal value is about understanding how the knowledge might be useful and can be connected to the acquired knowledge to his/her prior knowledge. Second, feeling in control pertains to learners' involvement in making decisions and being proactive rather than reactive learner. And third, taking responsibility means being accountable for the process of learning as well as the results.

Actually, ownership has been a common concept in many areas like psychology, economics, political science, philosophy, sociology, but it is comparatively a new concept in the field of education and training. With the emergence of constructivism as another epistemology in learning, ownership has also started gaining attention from educational researchers and theorists. Although it has already been initially explored for its potential benefit, further research is still required to conduct its affordances in the aspect of human learning.

On the other hand, Pierce et al. (2003) in their conceptual examination of psychological ownership proposed three human motives that serve as roots of this psychological state: efficacy and effectiveness, self-identity, and having a place to dwell. First, an efficacy and effectiveness can influence desired outcomes in our environment and control object in any way (Furby, 1978). In learning setting, an efficacy and/or effectiveness is also considered to be a very strong determinant to learners' motivation as illustrated in the work of Bandura (1986). It shows that self-efficacy influences on how individuals feel, think, motivate themselves and behave. Thus, it influences learners' choice and the amount of effort that he puts forth and his persistence at a given task. It is 
assumed that learners with higher self-efficacy would consider a difficult task as a challenge to master rather than treats to be avoided letting them approach learning with higher level of motivation and quickly recover their sense of efficacy after failures.

The second root of psychological ownership is self-identity. Pierce et al. (2003) proposes that ownership helps people come to define themselves, express their self-identity to others, and maintain the continuity of the self across time. Identity is the interface between the individual and society. An individual develops a sense of self-identity as a result of viewing oneself from the perspective of how others view him/her. As pleasure and comfort are found in interactions with objects, the socially shared meaning ascribed to those objects becomes part of the individuals' self-identity (McCracken, 1986). In addition to affording power over others, they communicate the individuals' identity to others.

Lastly, having a place to dwell is the third human motive that serves as another root of psychological ownership. According to Weil (1952), to have a place is an important "need of the human soul" (p.41). This can be formed to the idea being emphasized by Maslow (1954) on hierarchy of human needs wherein safety or security is on the second level of the hierarchy. Humans have an innate need of protecting themselves from all types of harm. So, having a place to dwell is a very important necessity for them.

The purpose of this study is to explore the development of a conceptual model that promotes ownership in an online learning environment. To conduct the study, Milner-Bolotin's three categories of ownership are employed. A conceptual model of learners' ownership in an online learning environment is to propose the integration of three factors of learning motivation, cognition, and meta-cognition, and Milner-Bolotin's three categories of ownership (2001), which are composed of finding personal value, feeling in control and taking responsibility.

\section{Three Categories of Ownership}

\subsection{Finding Personal Value}

Learners need rich motivation at the very outset of any instruction. During the process of learning, poor motivation can also cause learners to quit the course in online learning easily since this type of setting leaving the course is as easy as clicking the mouse button. Recently, online designers have been focusing on identifying ways of attracting and retaining learners' attention such as use of graphics, color, sound and animation (Ritchie \& Hoffman, 1997). However, these techniques are more of external stimuli which are just useful for perceptual arousal or gaining learners' initial attention which is considered as a short-lived motivation. In online learning, a more internal motive is highly demanded to sustain learners' motivation throughout the course. Establishing the usefulness or value of the material in relation to the learners' traits is one way to enhance motivation among learners in online learning.

Learning tasks must be linked with learners' needs, goals, values and interests, personal beliefs and even volition to ensure higher motivation or involvement of the learners. Tasks that are useful or valuable to the learner would elicit not only his attention, but his/her interest to pursue and persist during learning at the same time. Personal values and interest are also important factors influencing learners' motivation to learn. Every person comes into learning with a distinct set of stable or general beliefs about the desirability of a certain object or activity and with individual interests to be satisfied. Thus, instruction should try to meet these values and interest for the learners to get highly motivated. In the study of Milner-Bolotin (2001) on the effect of topic choice on learners' interest, ownership, and motivation in an offline learning, significant correlation between the learner interest and ownership had been observed. Therefore, matching instruction to learners' interest can promote ownership and motivation as well.

\subsection{Feeling in Control}

In online learning, being an open system confronts learners with greater control than in other delivery media. The most common and important things are controls given to learners in terms of navigation and presentation. One example is the freedom given to the learner in sequencing of information. Strict, linear, and designer-driven sequence is now being replaced by user-driven sequencing decision (Jones \& Farquhar, 1997). Although it can be noted that greater control does not benefit all types of learners, learners are motivated by having control of their learning rather than the program totally controlling the learning process (Allesi \& Trollip, 2001). When learners are required to do something to get a reward that a teacher control, resentment may occur because the teacher has taken over part of the learner's area of control over his/her life (Keller, 1987). One of the most important aspects of learner control is the design of navigational tools that allow learners to control the sequence of the learning process in online learning (Yang, 1993). It has been suggested that navigational freedom has an impact to the learners' control of the program. Learners feel that they have the control of the program when they 
are provided with navigational aids that offer many options than with few ones.

Trollip and Allesi (2001) mentioned that because we cannot be certain what purposes learners have for a program, the incorporation of different navigation methods facilitates different purposes and customized to the individuals need. In addition, they suggest the following strategies in designing learner control in online learning: (a) allowing the learner temporary termination of the program and return to it later with the use of bookmarking and do not use timed pauses, (b) allowing optional pacing which means learners should decide how fast the learning processes occur, (c) providing multiple orientation device that the learner can use at any time whenever the need arise such as directions, help, complaints, and glossaries, (d) providing appropriate controls for the learners' needs. These strategies clearly reflect that learners are given enough instructional options both for navigation and presentation process so they can customize the instruction based on their own preferences.

\subsection{Taking Responsibility}

Strategies such as self-goal setting and planning, supporting learners' cognitive strategies providing enough opportunities for learners' use of knowledge, and providing opportunities for self-evaluation can be included. Planning and goal setting influence not only learners' motivation but also their meta-cognition because they provide learners with criteria in evaluating their own performance. A good deal of research indicates that goal setting is related to different types of performance as well as learners belief related to achievement such as personal efficacy for self-regulated learning (Garavalia, \& Gredler, 2002). Learners with learning goals focus their attention on process of learning (Scott, 1996). However researchers found that allowing learners to set their goals enhances self-efficacy and learning (Schunk, \& Ertmer, 2000). Self-goal setting let learners experience control of their learning and be responsible for achieving the desired goals.

Another way of allowing learners to take responsibility of their learning is supporting their cognitive strategies. Instruction has to provide more opportunities for learners in exercising their cognitive strategies. Learners have to be more active in their cognitive process and they have to be provided with good activities for exercising rehearsal, elaboration and organization strategies to aid their cognitive process during online learning (Kim, 2008). Rehearsal is the repetition of the information to aid encoding into the memory. It can be in an oral manner by way of reciting a word or any piece of information aloud or in a written form by taking notes or highlighting words in a rather passive manner. Elaboration involves paraphrasing or summarizing the material learned and creating a generative note taking (Pintrich, 1999). Learners organize and connect ideas actively in their notes rather than taking notes passively and linearly. They also create analogies to fully understand materials to be learned, and explain ideas related with learning materials to someone else. Organization strategies include selecting the main idea from the text, making an outline of the material and using variety of specific techniques for selecting and organizing the ideas in the material by utilizing methods.

\section{Relationships of Ownership and Motivation, Cognition, and Meta-cognition}

\subsection{Ownership and Motivation}

Based on Schunk \& Ertmer's Model of Motivated Learning (2000), there are various variables affecting learner's motivation from the pre-task phase until the post-task that indicate the changing role of motivation from one phase to another. Considering these variables, it seems to be assumed that linking ownership strategies into some of these variables can be a very significant way to enhance motivation for the entire learning process. In the model proposed in this study, personal value is the first category of ownership strategies that can be linked into these motivational variables, especially in terms of goals, values, and needs to ensure well-motivated learners. Though it can be noticed that only goal, personal desires, and need variables are being emphasized, this study deemed it necessary to add values, personal beliefs, and volition as additional determinants of learners' motivation especially in the pre-task and post-task phase. Volition can be considered for its potential influence on learners' motivation for the whole learning process.

Goal reflects one's purpose and refers to quantity, quality, or rate of performance (Schunk, 1990). Goals motivate people to exert effort necessary to meet task demands and to persist on the task over time. Goals can be set by the individual himself or can be established by others. However, allowing the learners to set their own learning goals as a way of taking ownership in their learning has been assumed to be more effective. Researchers have found that allowing learners to set their goals enhances self-efficacy and learning, perhaps because self-set goals produce high goal commitment (Schunk, \& Ertmer, 2000). It is likely that before one can totally proceed with instruction in an optimal way, learners believe that it is related to their personal goals and will meet their specific needs (Driscoll, 2005). 


\subsection{Ownership and Cognition}

Cognition is the mental process of knowing, including aspects such as awareness, perception, reasoning, and judgment. It involves thinking, perceiving, abstracting, synthesizing, organizing, or any other process that allows the individual to conceptualize the nature of the external world (Franken, 1998). In the pursuit of trying to explain human behaviors especially in articulating how learning occurs, there are three theoretical perspectives: behaviorism, cognitivism and constructivism. Among them, it is known that cognitivism and constructivism emphasized the human factor more than the environment in the formation and modification of one's behavior. Behaviorists assume for a direct influence of the environment to behavior. In contrast, cognitive psychology places emphasis on unobservable constructs, such as the mind, memory, attitudes, motivation, thinking, reflection and other internal processes. It attempts to describe how information around the world enters through our senses is retained or forgotten. Ownership in learning can be explored for its potential implications to cognitive theory as it emphasized the significance of the role of attention and perception, memory, and active learning.

\subsection{Ownership and Meta-cognition}

Meta-cognition is the process of cognition about cognition. Being composed by self-awareness, reflection, and self-assessment, it can be related to the responsibility component of ownership in learning. Self-awareness is the learners' awareness of his own knowledge and ability levels. Reflection is the stopping and thinking about what one has been doing and where one is going while self-assessment refers to giving oneself tests either actual or mental to evaluate cognition process. The development of meta-cognitive ability is greatly influenced by a variety of variables. Understanding which skills and strategies help us process and remember information is necessary but not sufficient to enhance our achievement (Schunk, \& Ertmer, 2000). There are times that learners are fully aware of what helps them learn better and yet do not use them. One of the main reasons is the lack of understanding as to why, how, when, and where to use them in a particular situation. Hence, helping learners to gain a full understanding about the use of meta-cognitive strategies can boost their self-efficacy for performing well in the assigned task. Table 1 shows the potential ownership strategies classified into three components of learning and three categories of ownership in online learning.

Table 1. Potential ownership strategies between three components of learning \& three categories of ownership

\begin{tabular}{|c|c|c|}
\hline $\begin{array}{l}\text { Components of } \\
\text { Learning }\end{array}$ & $\begin{array}{l}\text { Categories of } \\
\text { Ownership }\end{array}$ & Potential Ownership Strategies \\
\hline \multirow[t]{7}{*}{ Motivation } & Personal Value & Relating the tasks to learners' needs and goals. \\
\hline & & Relating the tasks to learners' values and interest. \\
\hline & & $\begin{array}{l}\text { Relating the task to learners' ability, and successful achievements in } \\
\text { the past. }\end{array}$ \\
\hline & Control & $\begin{array}{l}\text { Providing multiple navigational aids and higher navigational } \\
\text { freedom. }\end{array}$ \\
\hline & & Providing ill-defined learning space. \\
\hline & Responsibility & Allowing learners to set their own learning goals. \\
\hline & & $\begin{array}{l}\text { Supporting learners in sustaining their motivation throughout the } \\
\text { whole process of learning. }\end{array}$ \\
\hline \multirow[t]{5}{*}{ Cognition } & Personal Value & $\begin{array}{l}\text { Relating the task to learners' prior knowledge and experience. } \\
\text { Allowing learners to use their own learning styles. }\end{array}$ \\
\hline & Control & Providing enough instructional options. \\
\hline & & Making instruction highly interactive. \\
\hline & Responsibility & Supporting learners in the use of their cognitive strategies. \\
\hline & & $\begin{array}{l}\text { Providing more opportunities for learners to use the newly gained } \\
\text { knowledge. }\end{array}$ \\
\hline \multirow[t]{5}{*}{ Meta-cognition } & Personal Value & $\begin{array}{l}\text { Guiding the learners to attribute the result of learning to their own } \\
\text { effort rather than luck or ease of task when appropriate. }\end{array}$ \\
\hline & Control & Allowing learners to monitor their own learning. \\
\hline & & Allowing learners to manage their own learning resources. \\
\hline & Responsibility & Providing learners enough opportunities for self-evaluation \\
\hline & & Support learners in redefining goals and planning. \\
\hline
\end{tabular}




\section{A Proposed Ownership Strategy Model}

A model of ownership strategy has been proposed with a spiral figure located at the center that depicts the process of learning with the active interplay of its three components. They are all indispensable variables of learning and they should work synergistically to achieve the desired learning outcomes.

The following Figure 1 shows the whole illustration of the final version of the ownership strategy model. The spiral figure starts at its inner most part and continuously expands following a series of loops. This implies the close and active interplay of the three components of learning in such a way that each component depends on each other throughout the learning process to arrive at the desired outcomes. It also depicts the ever dynamic nature of learning that is continuously undergoing change, making education a lifetime process. The outermost part of the figure is considered to be the area of learners' highest degree of ownership. The spiral figure is three boxes representing the categories of ownership with specific strategies under each category. Two-way directional arrows connect these three categories that illustrate their interrelatedness. Embedding the strategies into the components of learning is illustrated by three separate arrows from each category to link strategies directly to the individual component of learning. It is assumed that it is through the active interplay of all the variables in the model that learner ownership can be fostered.

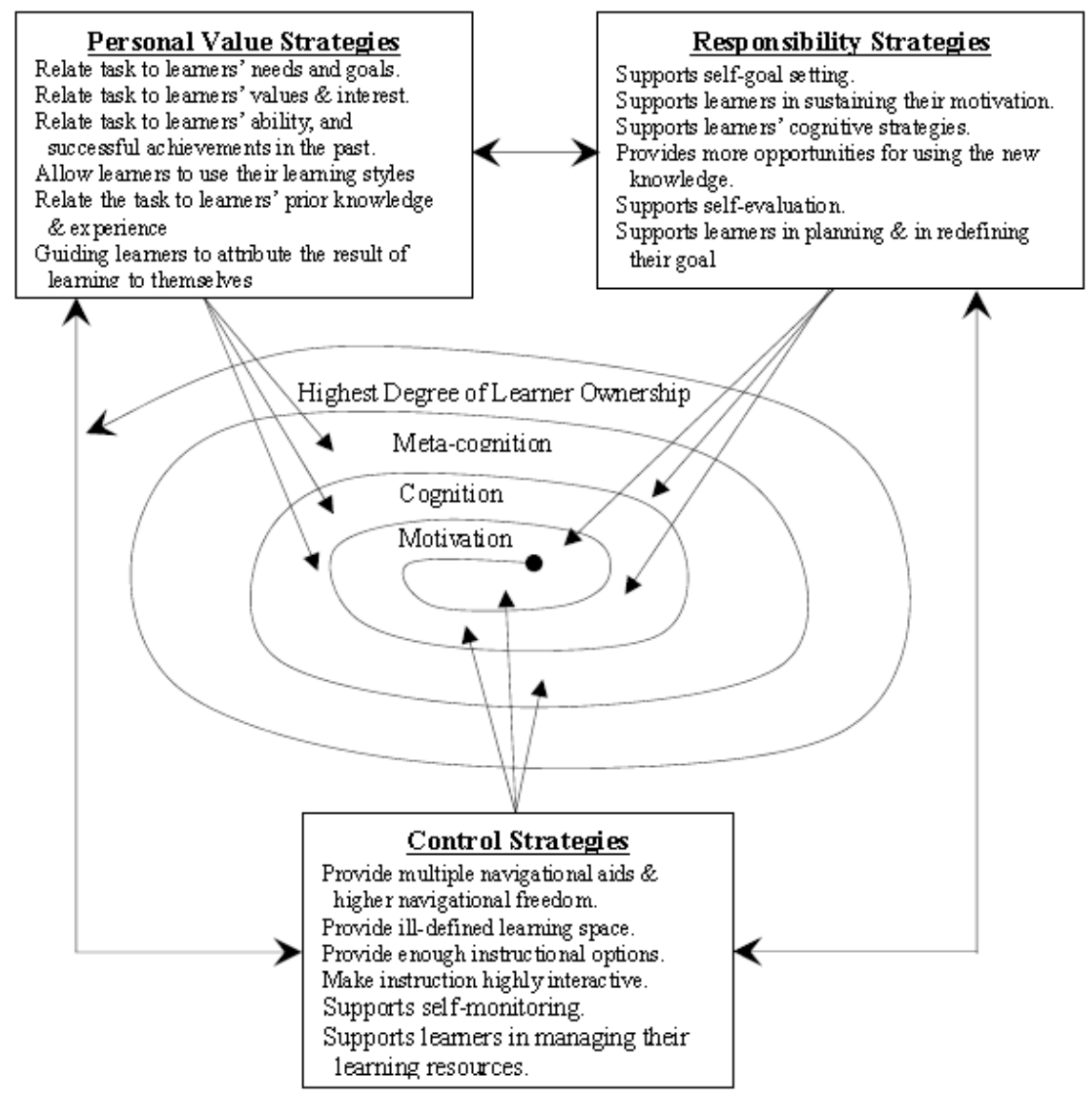

Figure 1. Proposed ownership strategies model in online learning

\section{Concluding Remarks}

With the belief that ownership greatly influences learners' achievement especially in online learning, this study was conducted to conceptualize ownership strategies model. Since online learning is desirable to be related with learners' personal value, it should allow more learner control and require learners to take responsibility of their own learning. Specific strategies that have potential in promoting ownership were investigated and integrated the three categories of personal value, control, responsibility about learner ownership into three components of motivation, cognition and meta-cognition. It is indicated that for learners to develop ownership over their learning the task should be related to their personal characteristics. Relating the task to learners' needs, goals, values, interest and abilities are only some of the strategies under the first category which is about finding personal value. Also, learners have to feel in control of the learning process by involving them in making 
decision as to how and what to learn. This can be done by designing good navigational aids that offer higher navigational freedom, providing ill-defined learning space, monitor and manage their learning resource and many others. Also, learners should feel responsible and accountable both for the process and outcomes of learning. This can be done by letting them set their own learning goals, supporting them in the use of their cognitive strategies and providing more opportunities to use the newly-gained knowledge. These potential ownership strategies will be embedded into the motivational, cognitive, and meta-cognitive design of instruction to promote learner ownership in online learning.

\section{References}

Allesi, S. M., \& Trollip, S. R. (2001). Multimedia for learning: Methods and development. Needham Heights, MA: Allyn \& Bacon.

Bandura, A. (1986). Social foundations of thought and action: A social-cognitive theory. Englewood Cliffs, NJ: Prentice-Hall.

Dittmar, H. (1992). The social psychology of material possessions: To have is to be. New York: St. Martin Press.

Driscoll, M. P. (2005). Psychology of learning for instruction (3rd ed.). Needham Heights, MA: Allyn \& Bacon.

Eccles, J. S. (1983). Expectancies, values, and academic behaviors. In J. T. Spence (Ed.), Achievement and Achievement Motivation (pp.75-146). San Francisco, CA: Freeman.

Furby, L. (1978). Possessions' in humans: An exploratory study of its meaning and motivation. Social Behavior and Personality, 6(1), 49-65. http://dx.doi.org/10.2224/sbp.1978.6.1.49

Garavalia, L. S., \& Gredler, M. E. (2002). An exploratory study of academia goal setting, achievement calibration and self-regulated learning. Journal of Instructional Psychology, 29(4), 221-230.

Jones, M. G., \& Farquhar, J. D. (1997). User interface design for web-based instruction. In B. H. Khan (Ed.), Web-based instruction. Englewood Cliffs, NJ: Educational Technology Publications.

Keller, J. M. (1987). Development and use of the ARCS model of instructional design. Journal of Instructional Development, 10(3), 2-10. http://dx.doi.org/10.1007/BF02905780

Kim, C-S. (2008). Development and utilization of self-regulatory tools to support e-Learning. Unpublished doctoral dissertation. Andong National University, Andong, Korea.

Maslow, A. H. (1954). Motivation and personality. New York: Harper.

McCracken, G. (1986). Culture and Consumption: A theoretical account of the structure and movement of the cultural meaning of consumer goods. Journal of Consumer Research, 17, 398-411.

Milner-Bolotin, M. (2001). The effects of topic choice in project-based instruction on undergraduate physical science students' interest, ownership, and motivation. Unpublished doctoral dissertation. University of Texas at Austin, Texas, USA.

Pierce, J. L., Kostova, T., \& Dirks, K. T. (2003). The state of psychological ownership: integrating and extending a century of research. Review of General Psychology, 7(1), 84-107. http://dx.doi.org/10.1037/1089-2680.7.1.84

Pintrich, P. R. (1999). The Role of motivation in promoting and sustaining self-regulated learning. Journal of Educational Research, 31, 459-470.

Ritchie, D. C., \& Hoffman, B. (1997). Incorporating instructional design principles with the World Wide Web. In B. H. Khan (Ed.), Web-Based Instruction. Englewood Cliffs, New Jersey: Educational Technology Publications.

Schunk, D. H. (1990). Goal setting and self-efficacy during self-regulated learning. Educational Psychologist, 25, 71-86. http://dx.doi.org/10.1207/s15326985ep2501_6

Schunk, D. H., \& Ertmer, P. A. (2000). Self-regulation and academic learning: Self-efficacy enhancing interventions. In M. Boekaerts, P. R. Pintrich, \& M. Zeidner (Eds.), Handbook of self-regulation (pp. 631-649). San Diego, CA: Academic Press. http://dx.doi.org/10.1016/B978-012109890-2/50048-2

Scott, J. E. (1996). Self-efficacy: A key to literacy learning. Reading Horizon, 36, 195-213.

Weil, S. (1952). The Need for Roots: Prelude to a declaration of duties towards mankind. London: Routledge.

Yang, Y-C. (1995). The effects of self-regulatory skills and type of instructional control on learning from computer-based instruction. International Journal of Instructional Media, 20(3), 225-241. 